\title{
Cotton response to mepiquat chloride and temperature
}

\author{
Ciro A. Rosolem ${ }^{*}$, Derrick M. Oosterhuis ${ }^{2}$, Fabio S. de Souza ${ }^{3}$
}

IUNESP/FCA - Depto. de Produção Vegetal, R. José Barbosa de Barros, 1780, C.P. 237 - 18610-380 Botucatu, SP - Brasil.

2University of Arkansas/Crop, Soil, and Environmental Sciences - 1366 W. Altheimer Drive - Fayetteville, AR 72704 - USA.

${ }^{3}$ APAR - Rod. Celso Garcia Cid, km 375, C.P. 481 - 86047-

902 - Londrina, PR - Brasil.

*Corresponding author <rosolem@fca.unesp.br>

Edited by: Daniel Scherer de Moura

Received September 16, 2011

Accepted December 12, 2012
ABSTRACT: Gibberellin inhibitor growth regulators are used for cotton (Gossypium hirsutum L.) canopy manipulation to avoid excess growth and yield losses. However, under temperatures below or over the optimum for cotton production the effect of mepiquat chloride (MC) has not always been significant. In this experiment, cotton plants were grown in growth chambers to study the response to $\mathrm{MC}$ as affected by temperature and to determine if an increase in dose could overcome the temperature effects. Mepiquat chloride was applied at rates of 0,15 and 30 $\mathrm{g}$ ai ha- ${ }^{-1}$ at the pinhead square stage. Plants were then grown under three temperature regimes: $25 / 15^{\circ} \mathrm{C}, 32 / 22{ }^{\circ} \mathrm{C}$, and $39 / 29^{\circ} \mathrm{C}$ (day/night temperatures) for 51 days. Higher temperatures increased plant height, reproductive branches, fruit number, fruit abscission, and photosynthesis per unit area, but decreased leaf area and chlorophyll. The largest effect of $\mathrm{MC}$ on plant height was observed when the daily temperature was $32{ }^{\circ} \mathrm{C}$, with nights of $22^{\circ} \mathrm{C}$, which was also best for plant growth. High temperatures not only decreased the effectiveness of $\mathrm{MC}$ on plant height control, but also caused lower dry matter and fruit number per plant. Low temperatures (25/15 ${ }^{\circ} \mathrm{C}$ ) decreased cotton growth and fruit retention, but a higher concentration of $\mathrm{MC}$ was required per unit of growth reduction as compared with $32 / 22^{\circ} \mathrm{C}$. At high temperatures, the rate of $\mathrm{MC}$ to be applied must be disproportionately increased, because either plant growth is impaired by high temperature lessening the effect of $\mathrm{MC}$, or degradation of $\mathrm{MC}$ within the plant is too rapid. Keywords: plant growth regulator, cotton growth, photosynthesis

\section{Introduction}

The use of plant growth regulators (PGR) is one of the strategies routinely used in cotton (Gossypium hirsutum L.) production for plant canopy manipulation, to hasten maturity, reduce plant height and to avoid yield decreases due to auto-shading (Hodges et al., 1991; O'Berry et al., 2009; Krieg and Kerby, 1985). Mepiquat chloride (MC), 1,1 dimethylpiperidinium, is a water soluble organic molecule, which is absorbed by the green parts and redistributed throughout the plant. MC inhibits gibberellic acid synthesis by stopping the conversion of geranlgeranyl diphosphate to ent-kaurene, consequently reducing cell enlargement and cell division rate (Srivastava, 2002). The decreased cell elongation after MC application may eventually result in lower cotton leaf area and number of reproductive branches (Kerby, 1985). Cotton plants treated with MC are typically more compact, with fewer nodes (Reddy et al., 1990), shorter internodes and fewer reproductive branches (Bogiani and Rosolem, 2009). As a result, MC controls plant height and earliness, thus facilitating crop management and harvest. Application of MC reduces leaf area per plant more than boll load; therefore, the number of bolls per leaf area unit is increased. Mepiquat chloride also concentrates boll set on lower sympodia, increasing the synchrony of boll maturation and demand for photosynthate (Gwathmey and Clement, 2010).

Photosynthesis rate may decrease in plants treated with MC because it affects RuBP carboxylase activity in plant leaves (Reddy et al., 1996). This effect can be observed $48 \mathrm{~h}$ after spraying and lasts for about three weeks (Hodges et al., 1991). However, net leaf photo- synthesis seems to be increased (Reddy et al., 1996), as a consequence of decreased photorespiration in plants treated with MC.

The effect of MC on cotton plants is affected by environmental conditions and is temperature dependent. Under supra or infra optimum temperatures the effect of MC on plant growth may be insignificant (Hodges et al., 1991). Reddy et al. (1990) reported that $30^{\circ} \mathrm{C}$ during the day and $20^{\circ} \mathrm{C}$ at night would be the optimum temperature regime for cotton growth. Considering that cotton growth decreases under high or low temperatures in a similar way as the response of MC, the effect of the plant regulator probably will be further impaired and might be insignificant as the temperature regime departs from the optimum.

Leaf area growth rate, total node number and plant height decrease linearly with MC concentrations increasing from 0 to $30 \mu \mathrm{g} \mathrm{g}^{-1}$ (Reddy et al., 1996). As the plant grows, additional applications of MC may be needed to keep a low growth rate for long periods. Mepiquat chloride dramatically reduced plant height and node number in proportion to a total MC amount up to $45 \mathrm{~g}$ $\mathrm{ha}^{-1}$, and this response was independent of how often the treatment was repeated (Yeates et al., 2002). Multiple mepiquat chloride treatments at various application rates are commonly used to manage cotton growth (Edmisten, 2006) in several cotton producing areas, starting at pinhead square. The first application should be done when the first bud of the first position shows a diameter of $3 \mathrm{~mm}$, which is usually observed from six to ten days (depending on the cultivar and region) after the beginning of bud formation. 
In summary, $\mathrm{MC}$ is very effective in controlling excessive cotton growth, but plant response to this PGR depends on environmental factors. Plant response for a given level of vegetative growth is highly dependent on temperature (Barrabé et al., 2007). The objective of this study was to quantify growth and physiological responses of cotton plants to temperature regimes and Mepiquat Chloride rates. It was hypothesized that plant response to MC would be impaired at infra or supra optimum temperatures and $\mathrm{MC}$ rate should be increased to overcome this effect.

\section{Materials and Methods}

Cotton (var. Latifolia, cv. Delta Opal) plants were grown on $2 \mathrm{~L}$ pots containing washed sand in a growth chamber set for a 12 -h photoperiod, with day/night temperatures of $30 / 20{ }^{\circ} \mathrm{C}$. Two plants were grown per pot and $300 \mathrm{~mL}$ half-strength nutrient solution (Hoagland and Arnon, 1950) was applied daily to maintain adequate nutrient and water levels. At pinhead square, 30 days after planting, mepiquat chloride (MC) rates of $0.0,15.0$ and $30.0 \mathrm{~g} \mathrm{ha}^{-1}$ a.i. were foliar sprayed with a $\mathrm{CO}_{2}$ backpack sprayer calibrated to deliver $150 \mathrm{~L} \mathrm{ha}^{-1}$. Plants were subsequently submitted to the following day/night temperature regimes: 25/15, $32 / 22$, and $39 / 29^{\circ} \mathrm{C}$, and were harvested 21 days after MC application. The temperatures were increased/decreased gradually.

At the time of MC application, the youngest expanded leaf from the main stem of each plant was labeled. Every two days the main vein length of this leaf was measured from top to bottom (insertion of the petiole) and plant height was measured every three days after MC application. Effects on photosynthesis were measured in ten cotton plants one day before plants were subjected to $\mathrm{MC}$ rates and temperature regimes, and then at 3, 7, 14 and 21 days. Net photosynthesis and fluorescence were measured at the same time in the fourth main-stem leaf from the top. Net photosynthesis was determined with an IRGA 6200 (Licor), and fluorescence measured using an OPTI-SCIENCES OS1-FL Modulated Fluorometer (Opti-Sciences, Tyngsboro, MA). Chlorophyll content was estimated at 3, 7, 14 and 21 days after MC application, also in the forth leaf of the main stem, using a SPAD meter (Konica Minolta Inc., Osaka, Japan).
At harvest, 21 days after MC application and 51 days after planting, the number of reproductive branches and reproductive structures was counted; leaf area was measured using an area meter LICOR 3100 (Licor Inc., Lincoln, NE). Dry matter weight was determined after plants were dried in a forced air oven at $60{ }^{\circ} \mathrm{C}$ for three days.

For each treatment, two replications were set in excess, i.e., instead of five replications there were seven replications. The two replicates in excess were harvested just before, six, 12 and 18 days after MC application and plant height and dry matter yields were determined. This was done in order to determine the correlation between plant height and dry matter yields, and eventually MC concentration in the plants (Reddy et al., 1996). This was necessary because plant dry matter had to be estimated to calculate plant MC concentration, but we could not harvest the sprayed plants. By determining plant height, dry matter was estimated using the regression. The amount of spray intercepted by cotton leaves was estimated by applying to the plants of these two extra replicates a solution with a mixture of Bright Blue (FD\&C-1) and Saturn-Yellow dyes at $0.184 \%$ each. Immediately after application the leaves were collected and washed in a known amount of distilled water, and absorbance was determined to estimate dilution and product deposition per unit of cotton leaf area. This value, combined with the dry matter estimated, was used to calculate plant MC concentration.

The results obtained for photosynthesis, SPAD readings and fluorescence are presented as percentage change relative to the control of each temperature treatment. The following expression was used: \% change in the treatment $=[($ treatment value - control value $) /$ control value]* 100 .

The experimental design was a $3 \times 3$ factorial with five replications. The results were submitted to ANOVA and means were compared using LSD $(p<0.05)$. Regressions were fit to plant growth data and the mean standard error was used to compare changes calculated in percentage.

\section{Results and Discussion}

At the low temperature treatments $\left(25 / 15^{\circ} \mathrm{C}\right.$ day/ night) cotton growth was severely reduced irrespective of MC application, as shown by decreased leaf area and dry matter yields (Figure 1, Table 1). At high temper-

Table 1 - Leaf area per plant and per fruit, and dry matter yields per plant as affected by temperature and mepiquat chloride (MC) rates.

\begin{tabular}{|c|c|c|c|c|c|c|c|c|c|}
\hline \multirow{2}{*}{$\begin{array}{l}\mathrm{MC} \\
\text { rate }\end{array}$} & \multicolumn{3}{|c|}{ Leaf area } & \multicolumn{3}{|c|}{ Leaf area/fruit } & \multicolumn{3}{|c|}{ Dry matter } \\
\hline & $25 / 15^{*}$ & $32 / 22$ & $39 / 29$ & $25 / 15$ & $32 / 22$ & $39 / 29$ & $25 / 15$ & $32 / 22$ & $39 / 29$ \\
\hline $\mathrm{g} \mathrm{ha}^{-1}$ & 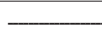 & $-\mathrm{cm}^{-2}$ & 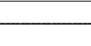 & 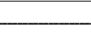 & $-\mathrm{cm}^{-2}$ & - & 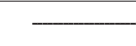 & $g$ & - \\
\hline 0.0 & 2400 & 4380 & 3800 & 198 & 203 & 271 & $30.0(13) \dagger$ & $50.5(12)$ & $38.4(10)$ \\
\hline 15.0 & 2550 & 3530 & 3250 & 225 & 187 & 290 & $32.0(13)$ & $40.2(11)$ & $29.6(9)$ \\
\hline 30.0 & 2490 & 3180 & 3110 & 249 & 181 & 279 & 28.1(12) & $39.1(12)$ & 28.3(9) \\
\hline LSD $\ddagger$ & & 470 & & & 51 & & & 5.5 & \\
\hline
\end{tabular}

${ }^{*}$ Temp. - Temperature in ${ }^{\circ} \mathrm{C} ; \dagger$ ( ) Specific Leaf Weight; $\ddagger$ Least significant difference $(p<0.05)$. 
atures $\left(39 / 29^{\circ} \mathrm{C}\right)$, leaf area was decreased only in the absence of $\mathrm{MC}$, but dry matter production was always lower than that observed under $32 / 22{ }^{\circ} \mathrm{C}$ (Table 1 ).

Mepiquat chloride decreased cotton leaf area and dry matter yields of plants under the $32 / 22$ and $39 / 29{ }^{\circ} \mathrm{C}$ temperature regimes. Leaf area may (Reddy et al., 1990) or may not (Souza and Rosolem, 2007) be decreased by MC. Bogiani and Rosolem (2009) observed that plants treated with this plant growth regulator tended to be narrower, with thicker and smaller leaves, resulting in total leaf area $16 \%$ smaller than the control, which was also observed by Zhao and Ooserhuis (2000). In the present experiment leaf thickening due to MC application was not always observed (results not shown), but leaves developed under higher temperatures had a lower leaf specific weight (Table 1). The leaf areas of MC treated plants were not decreased by the highest temperature, but there was a decrease in dry matter yields, resulting a lower leaf specific weight. Leaf area reduction is due to the plant growth regulator effect suppressing cell elongation (Srivastava, 2002), and smaller cells result in a general leaf area reduction. However, temperature regimes below or over the optimum may counteract this effect. Cotton response to MC depends on temperature, what may explain the different responses observed in other studies.

Cotton height after MC application increased with temperature (Figure 1), but was severely reduced at tem- peratures of $25 / 15{ }^{\circ} \mathrm{C}$, as it has been observed before (Reddy et al., 1990). The effect of the growth regulator was more evident at $32 / 22{ }^{\circ} \mathrm{C}$. At the highest temperature regime plant height was clearly less affected by MC application than at lower temperatures. Day temperatures of $30{ }^{\circ} \mathrm{C}$ combined with night temperatures of 20 ${ }^{\circ} \mathrm{C}$ were reported as ideal for cotton growth (Reddy et al., 1990). Under supra or infra optimum temperatures, the effect of MC on plant growth is impaired (Hodges et al., 1991), which is supported by our results. As observed in the present experiment, day/night temperatures of 32/22 ${ }^{\circ} \mathrm{C}$ fall within the best temperature range for $\mathrm{MC}$ to express its effects on cotton growth.

The higher the temperature the higher the number of reproductive branches produced per plant (Table 2). There was no effect of MC on the number of reproductive branches at the lower temperature regime, but at higher temperatures the number of reproductive branches was decreased with $15.0 \mathrm{~g} \mathrm{ha}^{-1}$, with no further decrease at the rate of $30.0 \mathrm{~g} \mathrm{ha}^{-1}$. MC decreases reproductive branches in cotton (Souza and Rosolem, 2007), but this effect depends not only on the rate applied, but also on the temperature, as shown in the present experiment. As a result of the number of reproductive branches and shedding, cotton grown at $32 / 22{ }^{\circ} \mathrm{C}$ had the highest number of reproductive structures (Table 2) 51 days after planting. Mepiquat chloride application decreased shedding at the highest temperature regime, but had no
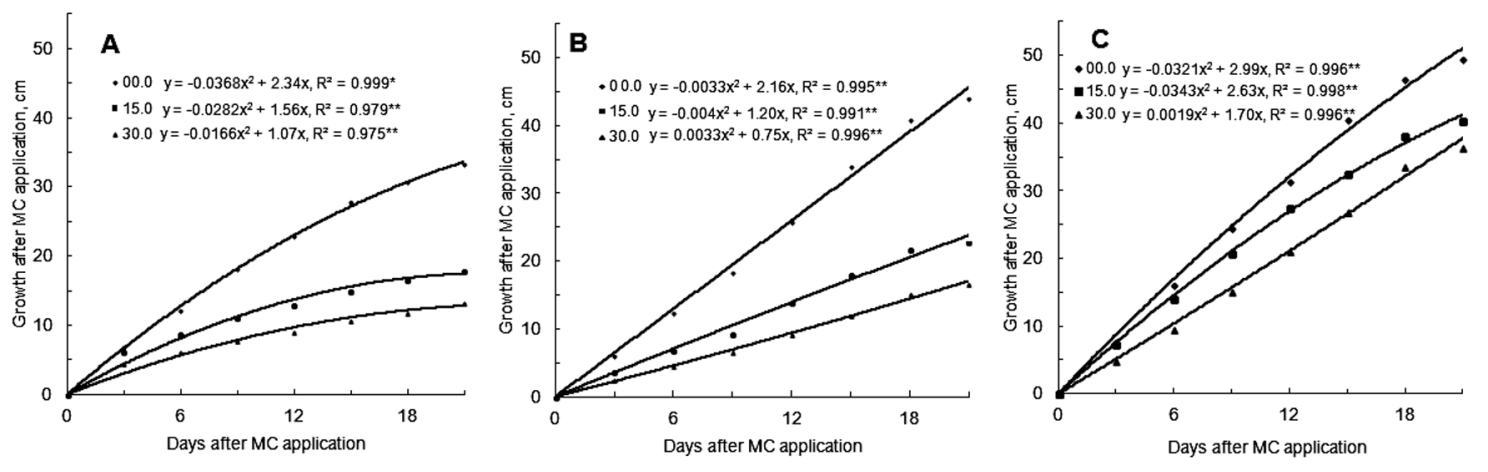

Figure 1 - Cotton plant growth (height) as affected by three mepiquat chloride (MC) concentrations and days after application at three temperature regimes a: $25 / 15{ }^{\circ} \mathrm{C}, \mathrm{b}: 32 / 22{ }^{\circ} \mathrm{C}$; c: rate of $39 / 29{ }^{\circ} \mathrm{C}$. ${ }^{*}$ Significant $(p=0.05) ;{ }^{*}$ Significant $(p=0.01)$.

Table 2 - Reproductive branches per plant, fruits (buds, flowers and bolls) and shedding as affected by temperature and mepiquat chloride (MC) rates applied to cotton plants.

\begin{tabular}{|c|c|c|c|c|c|c|c|c|c|}
\hline \multirow{2}{*}{ MC rate } & \multicolumn{3}{|c|}{ Reproductive branches } & \multicolumn{3}{|c|}{ Fruits } & \multicolumn{3}{|c|}{ Shedding } \\
\hline & $25 / 15^{*}$ & $32 / 22$ & $39 / 29$ & $25 / 15$ & $32 / 22$ & $39 / 29$ & $25 / 15$ & $32 / 22$ & $39 / 29$ \\
\hline $\mathrm{g} \mathrm{ha}^{-1}$ & & & -1 & & & & \multicolumn{3}{|c|}{ structures per plant } \\
\hline 0.0 & 8.5 & 9.0 & 10.2 & 12.1 & 21.5 & 14.0 & 0.35 & 0.20 & 5.3 \\
\hline 15.0 & 5.5 & 7.0 & 8.9 & 11.3 & 18.8 & 11.2 & 0.45 & 0.00 & 3.9 \\
\hline 30.0 & 4.9 & 6.7 & 8.0 & 10.0 & 17.5 & 11.5 & 0.25 & 0.00 & 2.4 \\
\hline LSD† & & 1.1 & & & 4.2 & & & 0.87 & \\
\hline
\end{tabular}

${ }^{*}$ Temp. - Temperature in ${ }^{\circ} \mathrm{C}$; $\uparrow$ Least significant difference $(p<0.05)$. 
effect $(p<0.05)$ on the fruit number. Hence, the best temperature regime for reproductive structure retention in cotton was day/night temperatures of $32 / 22{ }^{\circ} \mathrm{C}$. Maximum net photosynthesis in cotton leaves occurs around $32^{\circ} \mathrm{C}$ (Sung and Krieg, 1979), but respiration increases almost linearly with higher temperatures resulting in less carbohydrates available for fruit growth at high temperatures, fruit shedding and decreased yields; usually a good vegetative/reproductive balance in cotton is observed when the average temperature is around $25{ }^{\circ} \mathrm{C}$ (Pettigrew, 2008). The competition between vegetative and reproductive growth for photoassimilates is decreased by mepiquat chloride use (Gwathmey and Clement, 2010).

Photosynthesis rate one day before plants were submitted to temperatures day/night regimes averaged $24.2 \mu \mathrm{mol} \mathrm{CO} \mathrm{m}^{-2} \mathrm{~s}^{-1}$ (control). For both $\mathrm{MC}$ rates, photosynthetic rate was decreased (Figure 2). Seven days after spraying, the effect of temperature decreasing cotton photosynthesis was more evident, and remained up to 21 days. Accordingly, fluorescence values were higher at 7 and 14 days after MC application, but there was no effect of temperatures (Figure 3). The photosynthetic rate may be decreased in treatments submitted to MC due to a reduction of 1.5 ribulose diphosphate carboxylase activity, but the ratio between mepiquat choride use and carboxyilase accumulation in cotton plants is complex (Reddy et al., 1990). Hodges et al. (1991) observed that photosynthesis would be more efficient in plants treated
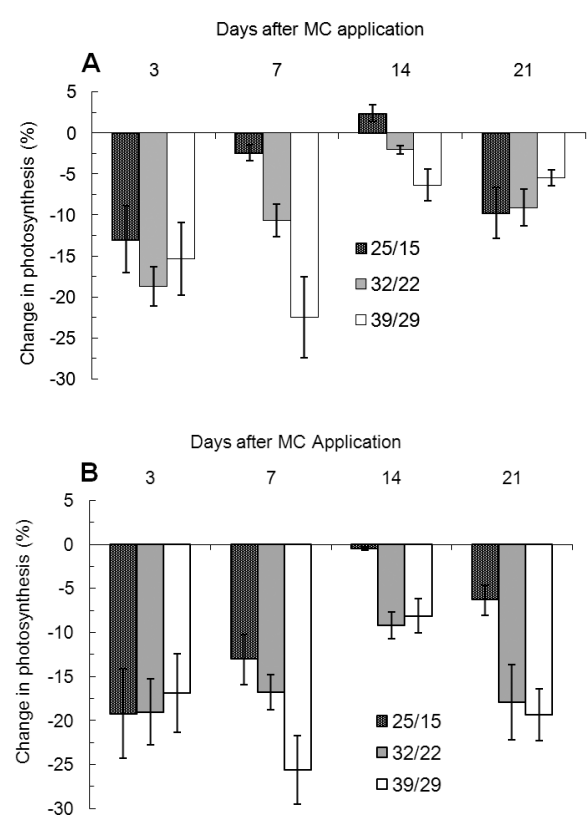

Figure 2 - Changes in cotton photosynthesis as affected by mepiquat chloride applied at three temperature regimes and at two rates: (A) $15 \mathrm{~g}$ ai ha- ${ }^{-1}$, and (B) $30 \mathrm{~g}$ ai ha ${ }^{-1}$ and time after application. Bars $=+/$ SE. with $\mathrm{MC}$ chloride due to a reduction in photorespiration. Increased leaf $\mathrm{CO}_{2}$ exchange rates by MC application was related to an increased specific leaf weight (Zhao and Oosterhuis, 2000), and in the present experiment plants exposed to the highest temperature regime had a lower specific leaf weight (Table 1). Hence, cotton leaf photosynthesis response to $\mathrm{MC}$ application is temperature dependent. According to Hodges et al. (1991), the effect of the product on photosynthesis occurs 48 hours after its application, persisting for approximately three weeks. During the vegetative stage, high day temperatures can cause damage to components of leaf photosynthesis, reducing carbon dioxide assimilation rates compared with environments having more optimal temperatures (Pettigrew, 2008). Gonias et al. (2008) observed decreases in cotton leaf photosynthesis and fluorescence when temperatures were above $35^{\circ} \mathrm{C}$. Sensitivity of photosynthesis to heat may be due mainly to damage to components of photosystem II located in the thylakoid membranes of the chloroplast and membrane properties (Hodges et al., 1991).

Plants submitted to extreme temperature conditions had higher fluorescence (Figure 3). The increase in fluorescence indicates some degree of stress, reflected in the photosynthetic rate (Figure 2). Plants under this kind of stress have no ability to capture and use the amount of energy they would have in an optimal developmental environment. This energy, thus, is lost through fluorescence and is not used for photosynthesis /carbohydrate
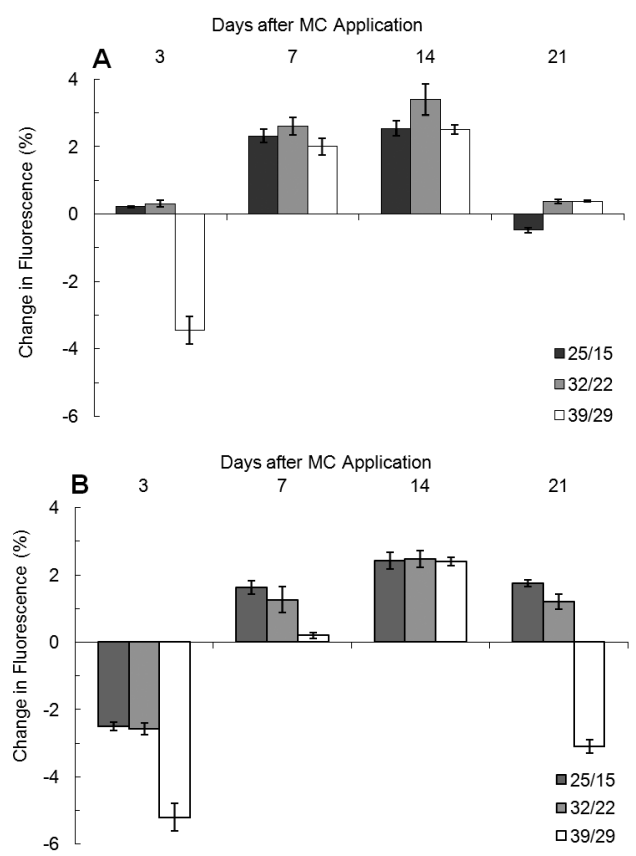

Figure 3 - Changes in cotton Fluorescence as affected by mepiquat chloride applied at three temperature regimes and two rates (A) $15 \mathrm{~g} \mathrm{ha}^{-1}$ and (B) $30 \mathrm{~g} \mathrm{ha}^{-1}$, with time after application. Bars = $+/$ SE. 
synthesis). The higher the fluorescence, the higher the amount of light reflected and, consequently, not used for photosynthesis.

In general, the leaf area per fruit increased with temperature (Table 1). Considering that the decrease in leaf area with temperatures increased from 32/22 to $39 / 29{ }^{\circ} \mathrm{C}$ were significant only in the absence of $\mathrm{MC}$, it is possible to infer that the lower net photosynthesis and higher fluorescence, i.e., less energy captured, was responsible for the higher shedding and lower number of fruits observed under the highest temperature regime.

Mepiquat chloride increased chlorophyll contents (SPAD) in cotton leaves (Figure 4). This effect is well known (Reddy et al., 1996), resulting leaves with a darker shade of green. However, this effect also depended on the temperature as the $25 / 15{ }^{\circ} \mathrm{C}$ regime resulted in the highest, and $39 / 29{ }^{\circ} \mathrm{C}$ led to the lowest, SPAD values. This effect persisted at least up to 21 days after MC application. However, this apparent increase or modification in chlorophyll did not result in more photosynthesis, growth and fruit retention.

Mepiquat chloride concentration in cotton, either absorbed or just retained in leaves, was increased by MC application. However, the effect upon plant height was strongly dependent on the temperature regime (Figure 1 and 5), as it was hypothesized (Reddy et al., 1996). At low $\left(25 / 15^{\circ} \mathrm{C}\right)$ or high $\left(39 / 29{ }^{\circ} \mathrm{C}\right)$ temperature regimes the effect of $\mathrm{MC}$ on cotton growth was significant. Conversely, at $32 / 22{ }^{\circ} \mathrm{C}$ the decrease in cotton height correlated linearly and negatively with MC concentrations (Figure 5).
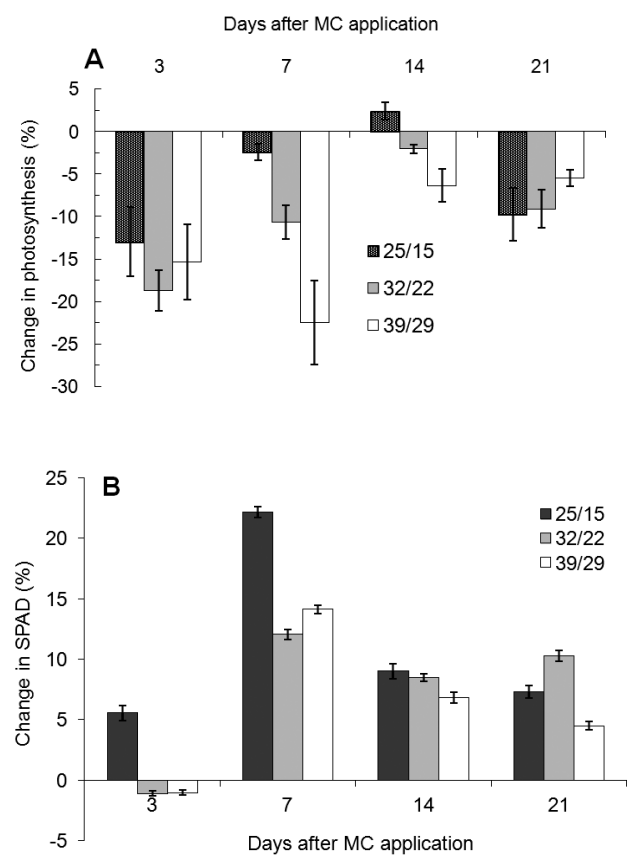

Figure 4 - Changes in chlorophyll contents (SPAD) in cotton leaves as affected by three temperature regimes and two rates of mepiquat chloride applied at (A) $15 \mathrm{~g} \mathrm{ha}^{-1}$, and (B) $30 \mathrm{~g} \mathrm{ha}^{-1}$ with and time after application. Bars $=+/$ - SE.

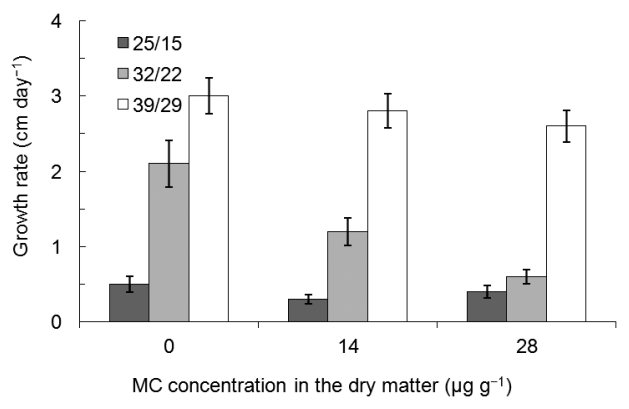

Figure 5 - Average growth rate (height) of cotton as affected by temperature regimes and mepiquat chloride concentration in the dry matter. Bars = +/- SE.

The results of the present experiment suggest that at low temperatures cotton growth may not be vigorous enough to require plant growth regulator application. However, if plant height control is needed, the rate of MC to be applied must not be lowered because the plant requires a higher concentration of the product per unit of growth reduction. Conversely, at high temperatures, the rate of $\mathrm{MC}$ to be applied must be disproportionately increased, because either plant absorption is impaired or its degradation within the plant is too fast. Under high temperatures, high MC rates may worsen the decrease in cotton yields caused by the temperature itself because photosynthesis may be further impaired.

\section{Conclusions}

Despite an increase in chlorophyll content of leaves, the application of mepiquat chloride does not prevent the decline in photosynthetic rate in cotton leaves observed at high temperatures. The temperature regime for optimal cotton growth was $32 / 22{ }^{\circ} \mathrm{C}$ day/ night temperatures, when the response to mepiquat chloride was maximum, with optimal plant growth including leaf area, dry matter, fruiting branches, photosynthesis and the least shedding. Increasing rates of MC generally decreased plant growth including leaf area, dry matter, number of fruiting branches, photosynthesis and chlorophyll. Day/night temperatures of $32 / 22{ }^{\circ} \mathrm{C}$ fall within the best temperature range for MC to express its effects on cotton growth. When the temperature is high, the plant requires disproportionately high concentrations of MC for each unit of height reduction.

\section{References}

Barrabé, A.; Rapicel, B.; Sissoko, F.; Traoré, B.; Wery, J. 2007. Elaboration and test of a decision rule for the application of mepiquat chloride on cotton in Mali. European Journal of Agronomy 27: 197-204.

Bogiani, J.C.; Rosolem, C.A. 2009. Sensibility of cotton cultivars to mepiquat chloride. Pesquisa Agropecuária Brasileira 44: 1246-1253 (in Portuguese, with abstract in English). 
Edmisten, K.L. 2006. Suggestions for growth regulator use. p. 5561. In: 2006 Cotton information. North Carolina Cooperative Extension Service, Raleigh, NC, USA.

Gonias, E.D.; Oosterhuis, D.M.; Bibi, A.C. 2008. Physiologic response of cotton to the insecticide imidacloprid under hightemperature stress. Journal of Plant Growth regulation 27: $77-82$.

Gwathmey, C.O.; Clement, J.D. 2010. Alteration of cotton sourcesink relations with plant population density and mepiquat chloride. Field Crops Research 116: 101-107.

Hoagland, D.R.; Arnon, D. 1950. The Water Culture Methods for Growing Plants without Soil. California Agricultural Experiment Station, Berkeley, CA, USA.

Hodges, H.F.; Reddy, V.R.; Reddy, K.R. 1991. Mepiquat chloride and temperature effects on photosynthesis and respiration of fruiting cotton. Crop Science 31: 1301-1308.

Krieg, D.R; Kerby, T.A. 1985. Cotton response to mepiquat chloride. Agronomy Journal 77: 907-912.

O'Berry, N.B.; Faircloth, J.C.; Jones, M.A.; Herbert, D.A.; Abaye, A.O.; Azenegashe, O.; McKemie, T.E.; Brownie, C. 2009. Differential responses of cotton cultivars when applying mepiquat pentaborate. Agronomy Journal 101: 25-31.

Pettigrew, W.T. 2008. The Effect of higher temperatures on Cotton lint yield production and fiber quality. Crop Science 48: 278285.
Reddy, V.R.; Baker, D.N.; Hodges, H.F. 1990. Temperature and mepiquat chloride on cotton canopy architecture. Agronomy Journal 82: 190-195.

Reddy, A.R.; Reddy, K.R.; Hodges, H.F. 1996. Mepiquat chloride (PIX)-induced changes in photosynthesis and growth of cotton. Plant Growth Regulation 20: 179-183.

Souza, F.S.; Rosolem, C.A. 2007. Rainfall intensity and mepiquat chloride persistence in cotton. Scientia Agricola 64: 125-130.

Srivastava, L.M. 2002. Gibberellins. p. 172-181. In: Srivastava, L.M. Plant growth and development Academic Press, New York, NY, USA.

Sung, F.J.M.; Krieg, D.R. 1979. Relative sensitivity of photosynthetic assimilation and translocation of " $4 \mathrm{C}$ to water stress. Plant Physiology 64: 852-856.

Yeates, S.J.; Constable, G.A.; McCumstie, T. 2002. Developing management options for mepiquat chloride in tropical winter season cotton. Field Crops Research 74: 217-230.

Zhao, D.; Oosterhuis, D.M. 2000. Pix plus and mepiquat chloride effects on physiology, growth, and yield of field-grown cotton. Journal of Plant Growth Regulators 19: 415-422. 